NBER WORKING PAPER SERIES

\title{
DISTRIBUTIONAL EFFECTS OF MEANS TESTING SOCIAL SECURITY: INCOME VERSUS WEALTH
}

\author{
Alan Gustman \\ Thomas Steinmeier \\ Nahid Tabatabai \\ Working Paper 22424 \\ http://www.nber.org/papers/w22424 \\ NATIONAL BUREAU OF ECONOMIC RESEARCH \\ 1050 Massachusetts Avenue \\ Cambridge, MA 02138 \\ July 2016
}

This work was supported by a grant from the Social Security Administration through the Michigan Retirement Research Center (UM14-01), with a subcontract to Dartmouth College. The findings and conclusions expressed are solely those of the authors and do not represent the views of the Social Security Administration, any agency of the Federal government, the Michigan Retirement Research Center or the NBER. We would like to thank Howard Iams, Erzo Luttmer and Steven Venti for helpful comments. Additional calculations are available in "Distributional Effects of Means Testing Social Security: An Exploratory Analysis, NBER Working Paper 20546, October, 2014. This paper is forthcoming in the National Tax Journal. The views expressed herein are those of the authors and do not necessarily reflect the views of the National Bureau of Economic Research.

NBER working papers are circulated for discussion and comment purposes. They have not been peer-reviewed or been subject to the review by the NBER Board of Directors that accompanies official NBER publications.

(C) 2016 by Alan Gustman, Thomas Steinmeier, and Nahid Tabatabai. All rights reserved. Short sections of text, not to exceed two paragraphs, may be quoted without explicit permission provided that full credit, including $(\odot$ notice, is given to the source. 
Distributional Effects of Means Testing Social Security: Income Versus Wealth

Alan Gustman, Thomas Steinmeier, and Nahid Tabatabai

NBER Working Paper No. 22424

July 2016

JEL No. D04,D31,D63,H55,I3,J14,J18,J32

\begin{abstract}
This paper compares Social Security means tests that would reduce benefits for recipients who fall in the top quarter of the income distribution with means tests aimed at those in the top quarter of the wealth distribution. Both means tests would reduce the average benefits for the affected groups by about $\$ 5,000$. The analysis is based on data from the Health and Retirement Study and covers individuals aged 69 to 79 in 2010.
\end{abstract}

About 14.5 percent of retirees in this age group are both in the top quarter of income recipients and in the top quarter of wealth holders. Another 10.5 percent are top quarter income recipients, but not top quarter wealth holders; with an additional 10.5 percent top quarter wealth holders, but not top quarter income recipients.

We find that a means test of Social Security based on income has substantially different distributional effects from a means test based on wealth. Moreover, there are substantial differences when a Social Security means test based on income is evaluated in terms of its effects on individuals arrayed by their wealth rather than their income. Similarly, a means test based on wealth will be evaluated quite differently by policy makers who believe that income is the appropriate basis for a means test than by those who believe that means tests should be based on wealth.

\author{
Alan Gustman \\ Department of Economics \\ Dartmouth College \\ Hanover, NH 03755-3514 \\ and NBER \\ alan.1.gustman@dartmouth.edu \\ Thomas Steinmeier \\ Department of Economics \\ Texas Tech University \\ Lubbock, TX 79409 \\ thomas.steinmeier@ttu.edu
}

\author{
Nahid Tabatabai \\ Department of Economics \\ Dartmouth College \\ Hanover, N.H. 03755 \\ Nahid.Tabatabai@dartmouth.edu
}


Social Security finances are out of balance. Future tax revenues will not be enough to cover promised benefits (Board of Trustees Report, 2015). To remedy this situation, some policy makers recommend increasing taxes. Others recommend reducing the growth of benefits, with some advocating means testing Social Security benefits. In this paper we explore the differences in the incidence of means testing when different definitions of means are used.

Popular discussions conflate income and wealth as measures of means. Warren Buffet and Bill Gates may be mentioned as examples of those whose Social Security benefits should be means tested, but it is never clear whether the focus is on their income, their wealth or both. Buffet and Gates fall in the top of both the income and wealth distributions, but many seniors with highest incomes do not have highest wealth, and similarly, those with highest wealth may not have highest incomes. Because income and wealth are not perfectly correlated, and neither is perfectly correlated with Social Security benefits, a given means test will have different distributional effects depending on the criteria used to define high means. For those policy makers who have thought about means testing Social Security, their proposals typically focus on incomes, but their rhetoric often suggests their concern is wealth. ${ }^{1} \mathrm{~A}$ major stumbling block to

\footnotetext{
${ }^{1}$ For an introduction to means testing Social Security and some of its consequences, and a list of plans that would base means tests on current income, see American Academy of Actuaries (2012). These include proposals by the Concord Coalition (reduce benefits beginning with family income of $\$ 40,000$ up through an 85 percent reduction in benefits for a family income of $\$ 120,000$; and The Heritage Foundation, which would begin reducing benefits at $\$ 55,000$ of non-Social Security income for single tax payers and $\$ 110,000$ for tax payers who file jointly, eliminating benefits when income exceeds these thresholds by $\$ 55,000$ or more. Some who vied for the Presidency in 2016 focused on means testing benefits. Although these candidates failed to make the cut in 2016, their views on means testing are representative of an important class of policy prescriptions. For example, in April, 2015, Governor Chris Christie proposed an income cap on Social Security benefits that would begin to reduce benefits of individuals with an income of $\$ 80,000$ and phase benefits out entirely if income exceeded $\$ 200,000$. Some plans for means testing, like Governor Christie's, are specific; others are more general. AARP set up a web site indicating the current and former candidates proposed changes in Social Security (2016takeastand.org). The website quotes Governor Kasich as follows: 'What you're going to have to do is that high-income seniors are going to get less. It would have to happen very soon,' Kasich said in a meeting that was webcast live. That means Americans earning more than an as-yet-undetermined amount would see their benefits scaled back." Senator Rubio's bullet points included "Reduce the growth in benefits for upper level seniors while strengthening the program for low-income seniors." Governor Bush was said to hold that the wealthiest of workers under his plan would get smaller Social Security checks during retirement ... otherwise known as means testing.
} 
basing a means test on wealth is that the Social Security Administration does not currently collect data on wealth. Nevertheless, means tests of many programs have been based on wealth, and basing a means test of Social Security on wealth is feasible. ${ }^{2}$

Our analysis begins with an examination of the joint distribution of income and wealth for individuals who were ages 69 to 79 in 2010 . We then consider the effects of a means test based on income applied to Social Security recipients who fall in the top quarter of income recipients. We examine the effects of a means test based on income on the distribution of Social Security benefits across the income distribution. Next we consider the effects of a means test based on income on the distribution of Social Security benefits for those falling in different parts of the wealth distribution. Following that, we evaluate a means test imposed on the top quarter of wealth holders. Once again we consider the effects on the Social Security benefits for those falling in different parts of the income and wealth distributions.

The analysis is based on data from the Health and Retirement Study. We use data as of 2010 for members of the original HRS cohort, those who were born from 1931 to 1941. Because these individuals were 69 to 79 years old by 2010, very few of them still remained in their main lifetime jobs. Indeed, as seen in Appendix Table 1A, earnings accounted for only 11.4 percent of the income of members of this cohort. This allows us to focus on the first order effects of means testing, postponing questions of labor supply response to later work. ${ }^{3}$

\footnotetext{
${ }^{2}$ Thus a number of transfer programs include a means test based on wealth (see Moffitt, 2016). Wealth data are also collected for determining student loans. Defined contribution plan balances from work in jobs not covered by Social Security are relevant for computing the Social Security benefits accrued by individuals who held other jobs that were covered. Their Social Security benefits are adjusted under Social Security's Windfall Elimination Provision (WEP) and Government Pension Offset (GPO) provisions. For further discussion of the importance of including wealth when measuring poverty, see Wimer and Manfield (2015).

${ }^{3}$ Current earnings are a major part of the current incomes of those in the population in their early to late sixties (See Social Security Administration, 2014). Thus if we applied a means test based on income to those in their early to mid-sixties, one could expect a major labor supply response. The induced disincentives to work would fly in the face of decades of policy initiatives that were designed to encourage older persons to delay their age of retirement. Facing a wave of baby boomer retirements, Congress abolished the Social Security earnings test for those between
} 
We do not advocate means testing of Social Security benefits, nor do we take sides on the question of whether to base a means test on income or wealth. Our aim is to clarify for policy makers the first order distributional consequences of means testing based on income or wealth.

To simplify the analysis, we restrict the form of the means test. We apply the means test to the top quarter of individuals when ranked by current income or wealth. ${ }^{4}$ To determine the size of the means test, we begin with a means test that would reduce Social Security benefits of affected individuals by $\$ 5,000$. This is roughly the equivalent of reducing the generosity coefficient in the formula for the Primary Insurance Amount (PIA) up to the first bend point (roughly $\$ 10,000$ ) from .9 to .4. This approach to reducing benefits has a precedent. A \$5,000 benefit reduction for affected individuals is similar to the reduction in benefits imposed by the Social Security Windfall Elimination Provision (WEP). This provision reduces Social Security benefits earned in covered employment when the individual also earned a pension from uncovered employment, primarily in the public sector. ${ }^{5}$

In a second step, we smooth the relation between the means test and the individual's income. Benefits are reduced proportionately to income (or wealth as appropriate), and the proportionate benefit reduction is scaled so that it generates the same total benefit reduction for the system as is realized by reducing the benefits of those in the top quarter of income recipients

the full retirement age and age 70; raised the full retirement age from 65 to 67; and increased to 8 percent the delayed retirement credit, the actuarial adjustment for delayed claiming of benefits. Other legislation and/or court decisions also encourage delayed retirement by abolishing various forms of age discrimination. Thus together with the courts, Congress abolished mandatory retirement; required defined benefit pensions to adopt actuarially fair adjustments in benefits for those who delay retiring until after age 65; and similarly required employers to continue to contribute to the defined contribution pension plans of those workers who are beyond the full retirement age specified by their plan.

${ }^{4}$ We realize that by focusing on the top quarter group we are introducing a notch. The adjustment we introduce below, basing the means test on the amount of current income, reduces the size of the notch.

${ }^{5}$ For further discussion, See Gustman, Steinmeier and Tabatabai (2014a). 
or wealth holders by about $\$ 5,000$. Our choice of initial benefit amount can easily be scaled to generate a larger or smaller benefit reduction. ${ }^{6}$

Section II discusses the population subject to means tests based on income or wealth. Section III analyzes the effects of income or wealth based means tests on Social Security benefits. Section IV reports related findings. Section V concludes. Appendix I briefly describes the major elements comprising income and wealth in the sample.

\section{The Populations Subject to Means Tests Based on Income or Wealth}

The sample includes age eligible individuals from HRS households who were first interviewed in 1992 and were again interviewed in 2010. Only age eligible individuals from these households (69 to 79 in 2010) are included. Members of households where at least one person held a job in uncovered employment are excluded, as are members of households that are not receiving Social Security income.

Total income for individual respondents in 2010 for the 1992 HRS cohort is based on the total income figure reported in the Rand HRS data file (http://www.rand.org/labor/aging/dataprod/hrs-data.html). Appendix Table 1 reports the components of income. Earnings account for 11.4 percent of income, with pension and Social Security benefits accounting for 18.1 percent and 43.6 percent respectively. ${ }^{7}$

\footnotetext{
${ }^{6}$ One caveat should be mentioned. We do not consider the potential of modifying the income tax to further means test Social Security benefits. Under current law, Social Security is subject to income tax if AGI is over $\$ 25,000$. For married couples filing jointly, the threshold is $\$ 44,000$. Income taxes are paid on up to 85 percent of Social Security benefits. More specifically, for couples filing jointly with incomes exceeding $\$ 44,000$, the amount of benefits counted in income is the lesser of 85 percent of Social Security or the sum of $\$ 6,000$ plus 85 percent of income over $\$ 44,000$. For singles, it is the lesser of 85 percent of Social Security or the sum of $\$ 4,500$ plus 85 percent of income over \$34,000. Social Security Bulletin, Annual Statistical Supplement, 2012, Table 2A31.The vast majority of Social Security benefits of high income individuals are already subject to the income tax. This leaves very little room for using the income tax per se as a basis for means testing Social Security benefits. For further analysis of the taxation of Social Security benefits under the income tax, see Purcell (2015).

${ }^{7}$ Note that when measuring the current income of retirees, some income originating from defined contribution pensions is attributed to other sources. For example, the HRS does not identify as pension income some irregular withdrawals from DC accounts that continue to be held throughout retirement. However, additional questions are included in the HRS pension and income sequences inquiring about other pension income and other income not
} 
In calculating wealth for individuals, we attribute half of the value of the house and other jointly held assets to each individual in married households. We add pension and Social Security wealth to the other elements of wealth reported in the Rand HRS data in $2010 .{ }^{8}$ For pension and Social Security wealth, we take the present values of pension and Social Security income flows from 2010 forward. ${ }^{9}$ The components of wealth are reported in Appendix Table 2. Pensions, Social Security and housing account for 9.4 percent, 28.2 percent and 22.0 percent of total wealth. Those who fall in the top or bottom 1 percent of the income distribution when considering income as the basis for the means test, and those who fall in the top or bottom 1 percent of the wealth distribution when considering wealth as the basis for the means test, are eliminated from the sample. We do this to reduce measurement error that might substantially affect a means test specified as a proportion of income or wealth, Income and wealth are far from perfectly related. Once calculated, income and wealth are correlated .50 among individuals. (Among households the correlation is .53, while within couple and individual households, wealth and income are correlated .50 in both cases.) Some of the larger recipients of Social Security benefits do not fall in the top of the income or wealth distributions. Moreover, some households will experience different reductions in Social Security benefits when the means test is based on income than when it is based on wealth.

reported. These questions are designed to capture income from live DC accounts that is not directly reported. In addition, at the time of retirement, pensions are sometimes transformed into other forms of assets. Income from these assets may not be attributed to pensions. Finally, note that while the income sequence in the HRS is designed to report realized income, such as withdrawals from DC accounts and regular payments from defined benefit plans, unrealized capital gains in DC accounts are not included in reported income. For comparisons of pension values measured before and after retirement and related discussions, see Gustman, Steinmeier and Tabatabai (2014b).

${ }^{8}$ Total wealth includes the present value of Social Security benefits, the present value of DB pensions, current assets in DC pension accounts, real estate, business, finance, vehicles, and IRA accounts. For respondents who have not yet retired, we calculate own Social Security benefits from working on a covered job by applying the Social Security Administration's ANYPIA program to the covered earning records for the respondent. When earnings or benefit records are not available from the Social Security Administration, we impute them based on individual and job characteristics, including self-reported earnings.

${ }^{9}$ In discounting pension and Social Security flows, we use a real interest rate of 2.8 percent and a nominal rate of 5.8 percent. These correspond to the long run rates in the Report of the Trustees (2015). We use a life table from the Social Security Administration that is not adjusted for place in the income distribution. 
Table 1: Percent of Respondents by Income and Wealth Percentages for Original HRS Cohort in 2010, Ages 69 to 79, weighted*

\begin{tabular}{|c|c|c|c|c|c|c|c|c|c|c|c|c|c|}
\hline $\begin{array}{l}\text { Wealth/ } \\
\text { Income }\end{array}$ & $\begin{array}{c}\text { Wealth } \\
0-25 \%\end{array}$ & $25-50 \%$ & $50-55 \%$ & $55-60 \%$ & $60-65 \%$ & $65-70 \%$ & $70-75 \%$ & $75-80 \%$ & $80-85 \%$ & $85-90 \%$ & $90-95 \%$ & $95-100 \%$ & Total \\
\hline \multicolumn{14}{|l|}{ Income } \\
\hline $0-25 \%$ & 15.57 & 5.53 & .67 & .56 & .52 & .46 & .52 & .23 & .28 & .32 & .22 & .15 & 25.03 \\
\hline $25-50 \%$ & 6.12 & 9.76 & 1.58 & 1.40 & 1.41 & .87 & 1.02 & 1.06 & .64 & .50 & .50 & .13 & 24.99 \\
\hline $50-55 \%$ & .55 & 1.96 & .32 & .41 & .10 & .44 & .30 & .14 & .24 & .31 & .08 & .14 & 4.99 \\
\hline $55-60 \%$ & .66 & 1.28 & .48 & .53 & .51 & .29 & .23 & .24 & .30 & .24 & .19 & .04 & 4.99 \\
\hline $60-65 \%$ & .43 & 1.46 & .50 & .46 & .22 & .30 & .31 & .28 & .28 & .28 & .32 & .16 & 4.99 \\
\hline $65-70 \%$ & .39 & .98 & .29 & .33 & .50 & .49 & .50 & .50 & .26 & .31 & .33 & .11 & 5.01 \\
\hline $70-75 \%$ & .37 & 1.05 & .49 & .33 & .39 & .27 & .41 & .32 & .47 & .45 & .21 & .21 & 4.99 \\
\hline $75-80 \%$ & .20 & .84 & .21 & .28 & .37 & .70 & .33 & .47 & .51 & .33 & .40 & .37 & 4.99 \\
\hline $80-85 \%$ & .20 & .67 & .15 & .24 & .32 & .52 & .55 & .62 & .30 & .67 & .46 & .32 & 5.03 \\
\hline $85-90 \%$ & .27 & .69 & .12 & .13 & .29 & .20 & .40 & .36 & .67 & .60 & .73 & .52 & 4.98 \\
\hline $90-95 \%$ & .01 & .52 & .07 & .14 & .22 & .18 & .33 & .48 & .57 & .69 & .88 & .89 & 5.0 \\
\hline $95-100 \%$ & .21 & .29 & .09 & .16 & .19 & .25 & .13 & .27 & .46 & .32 & .69 & 1.92 & 4.99 \\
\hline Total & 24.98 & 25.03 & 4.98 & 4.99 & 5.04 & 4.96 & 5.03 & 4.99 & 4.99 & 5.03 & 5.03 & 4.97 & 100 \\
\hline
\end{tabular}

Respondents with top and bottom one percent of total income, out of range age range respondents, and those without Social Security income are excluded.

*Weights used to create income and wealth brackets are from 1992. Observations reported in each cell are unweighted. 
Table 1 provides baseline data for judging the relations between the distributions of income and wealth. ${ }^{10}$ Row heads indicate place in the income distribution. Column heads pertain to the individual's place in the wealth distribution. To make the table more manageable, the first two row heads and the first two column heads pertain to individuals falling in the bottom two quarters of the distribution. (We are focusing on policies affecting the top quarter of income recipients or wealth holders.) After that the columns are based on ventiles ranging from 50 to 100 percent.

After exclusion of the top and bottom one percent of income recipients, 14.50 percent of individuals are both in the top quarter of income recipients and the top quarter of wealth holders; 10.47 percent have the top quarter of income, but not the top quarter of wealth; and 10.44 percent fall in the top quarter of wealth holders, but not in the top quarter of income recipients.

Define the potentially affected group as the 35.41 percent of individuals who have the top quarters of income and/or wealth. Those who view only income as the proper criteria for a means test, or only wealth, will agree on applying the test to only 41 percent (14.5/35.41) of the potentially affected group. The application of the means test to 59 percent of affected individuals will be in dispute. From the perspective of a policy maker who feels that wealth is the appropriate measure of means, a means test aimed at the top quarter of income recipients will hit $29.6(10.47 / 35.41)$ percent of individuals who should not be subject to a means test, and will miss 29.5 percent $(10.44 / 35.41)$ of individuals who fall in the top quarter of wealth holders, but not the top quarter of income recipients. Should a means test based on wealth be instituted, analogous errors will be perceived by those who feel that a means test should be based on income, not wealth.

\footnotetext{
${ }^{10}$ An alternative table that excludes individuals falling in the top and bottom one percent of the wealth distribution differs very slightly from Table 1.
} 
Similarly, many of those who fall in the top five percent of individuals ranked by income are not among those who fall in the top five percent of wealth holders. Looking across the next to bottom row of Table 1, only 38 percent (1.92/4.99) of individuals who are in the top 5 percent of income recipients also are included among the wealthiest 5 percent of individuals. Looking down the next to last column, 39 percent (1.92/4.97) of individuals falling within the top 5 percent of wealth holders also fall within the top 5 percent of income recipients.

Having counted the number of individuals who are affected by a means test based on income and/or wealth, in Table 2 we consider the income and wealth levels of these affected individuals. The average income and wealth for those falling in each cell correspond to the top and bottom figure in the cell respectively. For example, among those individuals with the highest 5 percent of income and wealth, average income is $\$ 135,600$ and average wealth is $\$ 2,552,700$. 
Table 2: Average Income \& Wealth by Income and Wealth Percentages for Original HRS Cohort Ages 69 to 79 in 2010 , weighted

\begin{tabular}{|c|c|c|c|c|c|c|c|c|c|c|c|c|c|}
\hline $\begin{array}{l}\text { Wealth/ } \\
\text { Income }\end{array}$ & $\begin{array}{l}\text { Wealth } \\
0-25 \%\end{array}$ & $25-50 \%$ & $50-55 \%$ & $55-60 \%$ & $60-65 \%$ & $65-70 \%$ & $70-75 \%$ & $75-80 \%$ & $80-85 \%$ & $85-90 \%$ & $90-95 \%$ & $95-100 \%$ & Average \\
\hline Income & $8.6^{*}$ & 9.2 & 9.7 & 9.5 & 9.2 & 9.7 & 9.0 & 10.0 & 9.7 & 8.9 & 9.4 & 10.8 & 8.9 \\
\hline $0-25 \%$ & $117.1^{* *}$ & 249.1 & 359.0 & 402.8 & 443.1 & 502.4 & 562.5 & 629.3 & 749.0 & 913.6 & $1,268.5$ & $3,872.4$ & 237.1 \\
\hline \multirow[t]{2}{*}{$25-50 \%$} & 15.4 & 16.4 & 16.6 & 17.0 & 16.8 & 17.3 & 16.9 & 17.2 & 16.1 & 17.3 & 16.2 & 17.0 & 16.3 \\
\hline & 145.0 & 254.6 & 358.6 & 395.0 & 447.1 & 499.7 & 564.1 & 643.3 & 735.8 & 878.8 & $1,155.3$ & $3,963.4$ & 352.6 \\
\hline \multirow[t]{2}{*}{$50-55 \%$} & 21.4 & 21.5 & 21.4 & 21.5 & 21.8 & 21.5 & 21.6 & 21.0 & 21.4 & 21.7 & 21.5 & 21.8 & 21.5 \\
\hline & 139.0 & 268.5 & 358.7 & 393.5 & 431.5 & 501.6 & 568.2 & 656.9 & 733.9 & 875.7 & $1,149.3$ & 2,219.9 & 453.7 \\
\hline \multirow[t]{2}{*}{$55-60 \%$} & 23.8 & 23.7 & 23.9 & 24.0 & 23.9 & 24.0 & 23.7 & 23.6 & 24.2 & 24.1 & 24.1 & 24.5 & 23.9 \\
\hline & 159.1 & 270.1 & 356.1 & 396.6 & 447.1 & 501.6 & 564.3 & 628.6 & 751.9 & 877.8 & $1,280.3$ & $2,360.8$ & 452.7 \\
\hline \multirow[t]{2}{*}{$60-65 \%$} & 26.9 & 26.6 & 26.5 & 26.8 & 26.3 & 26.9 & 27.1 & 26.4 & 26.6 & 26.6 & 26.7 & 26.9 & 26.7 \\
\hline & 144.1 & 287.7 & 355.9 & 399.3 & 447.3 & 505.0 & 571.7 & 658.4 & 738.6 & 902.1 & $1,099.7$ & $2,454.4$ & 533.5 \\
\hline \multirow[t]{2}{*}{$65-70 \%$} & 29.9 & 30.1 & 30.7 & 30.4 & 29.9 & 30.1 & 29.8 & 30.1 & 30.3 & 30.1 & 30.0 & 30.0 & 30.1 \\
\hline & 154.0 & 270.3 & 356.8 & 400.1 & 447.8 & 497.8 & 560.7 & 647.8 & 758.6 & 898.6 & $1,172.5$ & $2,632.5$ & 559.9 \\
\hline \multirow[t]{2}{*}{$70-75 \%$} & 34.3 & 34.0 & 34.0 & 34.1 & 33.9 & 33.9 & 34.1 & 33.8 & 34.1 & 34.3 & 34.5 & 34.0 & 34.1 \\
\hline & 140.0 & 265.6 & 355.5 & 392.1 & 444.5 & 505.8 & 569.9 & 641.6 & 737.2 & 887.2 & $1,097.4$ & 2,391.9 & 575.9 \\
\hline \multirow[t]{2}{*}{$75-80 \%$} & 39.3 & 39.5 & 38.7 & 37.7 & 38.5 & 38.7 & 38.5 & 39.0 & 38.7 & 39.3 & 38.9 & 39.4 & 38.9 \\
\hline & 172.5 & 258.4 & 360.5 & 395.2 & 450.9 & 505.4 & 565.3 & 645.3 & 744.1 & 907.3 & $1,186.9$ & $1,887.3$ & 659.3 \\
\hline \multirow[t]{2}{*}{$80-85 \%$} & 45.8 & 45.0 & 43.8 & 46.0 & 45.3 & 45.5 & 46.7 & 44.6 & 45.8 & 45.4 & 45.4 & 45.2 & 45.4 \\
\hline & 155.1 & 271.4 & 358.8 & 410.0 & 447.8 & 504.6 & 558.9 & 649.2 & 755.1 & 896.6 & $1,208.9$ & $2,194.2$ & 712.0 \\
\hline \multirow[t]{2}{*}{$85-90 \%$} & 55.2 & 54.8 & 56.2 & 54.2 & 55.2 & 55.3 & 55.6 & 55.2 & 54.1 & 55.7 & 54.6 & 55.1 & 55.0 \\
\hline & 136.2 & 263.9 & 353.3 & 395.5 & 444.5 & 502.0 & 563.5 & 648.5 & 746.9 & 900.3 & $1,182.9$ & $2,131.1$ & 804.2 \\
\hline \multirow[t]{2}{*}{$90-95 \%$} & 69.4 & 72.0 & 69.3 & 68.9 & 71.6 & 71.3 & 70.7 & 69.2 & 69.9 & 69.7 & 71.4 & 74.1 & 71.2 \\
\hline & 82.3 & 257.6 & 355.1 & 396.6 & 443.6 & 502.8 & 565.5 & 645.9 & 751.2 & 913.2 & $1,198.8$ & $2,462.6$ & $1,041.6$ \\
\hline \multirow[t]{2}{*}{$95-100 \%$} & 135.5 & 115.5 & 103.7 & 143.4 & 136.5 & 124.1 & 95.5 & 114.8 & 117.2 & 118.2 & 130.8 & 135.6 & 127.9 \\
\hline & 129.5 & 275.9 & 364.8 & 388.1 & 443.6 & 500.7 & 562.3 & 641.6 & 749.8 & 866.4 & $1,250.0$ & $2,552.7$ & $1,412.9$ \\
\hline \multirow[t]{2}{*}{ Average } & 14.1 & 22.4 & 25.3 & 29.4 & 32.5 & 35.0 & 33.3 & 38.8 & 44.3 & 43.6 & 54.1 & 81.9 & 30.0 \\
\hline & 127.9 & 259.4 & 357.8 & 397.0 & 446.1 & 502.3 & 564.3 & 645.0 & 745.4 & 894.8 & $1,192.2$ & $2,477.3$ & 507.6 \\
\hline
\end{tabular}

*Average income. **Average Wealth. Average income and wealth reported in $\$ 000$ dollars.

Respondents with top and bottom one percent of total income, out of range age range respondents and respondents without Social Security income are excluded. 
Table 3: Social Security Income and Reduction in Benefits from an Income Test, by Place in the Income and Wealth Distribution, Original HRS Cohort in 2010, Ages 69 to 79, weighted

\begin{tabular}{|c|c|c|c|c|c|c|c|c|c|c|c|c|c|}
\hline $\begin{array}{l}\text { Wealth/ } \\
\text { Income }\end{array}$ & $\begin{array}{l}\text { Wealth } \\
0-25 \%\end{array}$ & $25-50 \%$ & $50-55 \%$ & $55-60 \%$ & $60-65 \%$ & $65-70 \%$ & $70-75 \%$ & $75-80 \%$ & $80-85 \%$ & $85-90 \%$ & $90-95 \%$ & $95-100 \%$ & $\begin{array}{c}\text { Row } \\
\text { Average }\end{array}$ \\
\hline Income & 12.4 & 13.7 & 18.5 & 18.3 & 17.6 & 15.0 & 15.8 & 13.8 & 17.4 & 15.0 & 18.0 & 15.3 & 15.7 \\
\hline $75-80 \%$ & -2.9 & -2.8 & -2.9 & -2.8 & -2.8 & -2.7 & -2.8 & -2.9 & -2.9 & -2.9 & -2.9 & -2.9 & -2.8 \\
\hline \multirow[t]{2}{*}{$80-85 \%$} & 12.1 & 14.6 & 15.2 & 16.3 & 19.4 & 14.3 & 18.9 & 17.5 & 17.2 & 16.3 & 15.9 & 15.8 & 16.2 \\
\hline & -3.4 & -3.3 & -3.2 & -3.4 & -3.3 & -3.4 & -3.4 & -3.3 & -3.4 & -3.4 & -3.4 & -3.3 & -3.3 \\
\hline \multirow[t]{2}{*}{$85-90 \%$} & 9.1 & 15.2 & 15.5 & 14.1 & 17.2 & 16.2 & 16.7 & 16.0 & 17.0 & 17.2 & 16.4 & 16.5 & 16.0 \\
\hline & -4.0 & -4.1 & -4.2 & -4.0 & -4.1 & -4.1 & -4.1 & -3.9 & -3.9 & -4.1 & -4.0 & -4.1 & -4.0 \\
\hline \multirow[t]{2}{*}{$90-95 \%$} & 7.2 & 14.9 & 17.6 & 17.5 & 17.2 & 21.7 & 16.1 & 19.6 & 19.0 & 17.7 & 17.0 & 15.8 & 17.2 \\
\hline & -5.1 & -5.3 & -5.1 & -5.0 & -5.3 & -5.3 & -5.2 & -5.1 & -5.2 & -5.0 & -5.2 & -5.4 & -5.2 \\
\hline \multirow[t]{2}{*}{$95-100 \%$} & 14.8 & 18.8 & 16.8 & 20.0 & 14.4 & 17.2 & 16.7 & 15.7 & 17.8 & 19.3 & 17.4 & 16.4 & 17.0 \\
\hline & -9.3 & -8.5 & -7.7 & -10.6 & -8.3 & -8.9 & -7.1 & -8.3 & -8.4 & -8.7 & -8.9 & -9.1 & -8.9 \\
\hline \multicolumn{14}{|l|}{ Average } \\
\hline for top & 11.8 & 14.9 & 16.8 & 17.4 & 17.4 & 15.9 & 17.1 & 16.7 & 17.6 & 17.1 & 16.9 & 16.1 & 16.4 \\
\hline $\begin{array}{l}\text { quarter of } \\
\text { income } \\
\text { recipients }\end{array}$ & -4.9 & -4.2 & -4.1 & -4.8 & -4.4 & -4.1 & -4.1 & -4.3 & -4.8 & -4.6 & -5.2 & -6.6 & -4.9 \\
\hline
\end{tabular}

Average annual Social Security income (top number in each cell) and reduction in benefits from income test (bottom number) are in \$(000) dollars. Respondents with the top and bottom one percent of total income, out of range age respondents and respondents without Social Security income are excluded. Total benefits are not allowed to fall below zero after the means test. 
Looking across the next to bottom row of the table, we see that among the top 5 percent of individuals ranked by income, their wealth falls to as low as $\$ 129,500$ (including their Social Security). And among the top 5 percent of wealth holding individuals, their average income falls to as low as $\$ 10,800$. Clearly there is great variation in the income and wealth of populations selected for means tests based on either criterion. ${ }^{11}$

\section{The Effects on Benefits of Means Testing Based on Income and Wealth}

Next consider the effect of a means test based on income on those in different parts of the income and wealth distributions. Table 3 indicates the size of the Social Security benefit before the means test, and the benefit adjustment based on the means test.

Because the means test only affects those falling in the top quarter of income recipients, Table 3 excludes rows with respondents who fall in the bottom 75 percent of the income distribution. Had those rows been included, the benefit reduction reported for those falling in those rows would be zero.

The top number in each cell reports the baseline Social Security benefit for members of the cell before it is reduced by the means test. The bottom number in each cell reports the reduction in the benefit due to the means test based on income.

\footnotetext{
${ }^{11}$ One might consider asking about the effects of a means test based on an average of income or wealth calculated over a longer period. Averaging would reduce transitory fluctuations in these measures and thereby increase the correlation between them. For example, a high wealth individual is likely to have lower income in years he doesn't realize capital gains and higher income in years he does. Averaging over a few years would, however, complicate reporting, thereby increasing the costs of a means test.

Ironically, a measure of average earnings is readily available over a very long period. Average Indexed Monthly Earnings (AIME) measures covered earnings over the individual's working life. The Social Security Administration already calculates this measure because it is the basis for calculating Social Security benefits. So calculating AIME is not an additional administrative burden. Because Social Security benefits are already based on AIME and are redistributive, to understand the effects of a means test based on AIME, one must calculate the additional redistribution fostered by an AIME based means test. We have made the required calculations and have compared the additional redistribution from an AIME based means test with the redistribution under a means test that uses wealth as a measure of means. The means tests based on each criterion are then evaluated according to the relevant criterion. For further details, see Gustman, Steinmeier and Tabatabai (2014c).
} 
From the cell in the bottom row, right hand column, the average benefit for the top quarter of income recipients is $\$ 16,400$. The means test reduces the average benefit by $\$ 4,900$. This is slightly less than the $\$ 5,000$ baseline reduction built into the policy because we do not allow Social Security benefits to become negative. For the sample of top quarter of income recipients as a whole, the benefit reduction amounts to 29.9 percent (4.9/16.4) of the annual reported benefit.

From the cell in row 5, next to last column (which includes those who fall in the top 5 percent of income and wealth recipients), the benefit reduction amounts to 55.5 percent of the basic benefit (9.1/16.4). Those in the cell falling in the top row, left hand column, who are in the lower quarter of wealth holders and who fall within the $75^{\text {th }}$ to $80^{\text {th }}$ percentile of income recipients, their benefits are reduced by 23.4 percent (2.9/12.4).

Consider how this income based means test is evaluated by a policy maker who believes that means should be based on wealth. From the next to bottom row of Table 3, column 1, while the average Social Security benefit of a person who falls in the bottom quarter of the wealth distribution, but top five percent of the income distribution is $\$ 14,800$, the benefit reduction on average is $\$ 9,300$, or 62.8 percent of the basic benefit. For a person who falls in the top 5 percent of the wealth distribution, next to last column, bottom row, the average benefit is $\$ 16,100$, but the reduction in the benefit due to the income based means test is $\$ 6,600$, or 41 percent. That is, a person falling in the bottom quarter of the wealth distribution is experiencing a proportionate benefit reduction rate that is half again as large as the reduction rate experienced by a person in the top 5 percent of the wealth distribution. 
Table 4: Social Security Income and Benefit Reduction from a Wealth Test, Original HRS Cohort in 2010, Ages 69 to 79, weighted

\begin{tabular}{|c|c|c|c|c|c|c|}
\hline $\begin{array}{l}\text { Wealth/ } \\
\text { Income }\end{array}$ & $\begin{array}{l}\text { Wealth } \\
75-80 \%\end{array}$ & $80-85 \%$ & $85-90 \%$ & $90-95 \%$ & $95-100 \%$ & $\begin{array}{c}\text { Average for } \\
\text { top quarter of } \\
\text { wealth holders }\end{array}$ \\
\hline Income & 8.2 & 7.7 & 7.9 & 8.5 & 6.8 & 7.9 \\
\hline $0-25 \%$ & -2.6 & -3.1 & -3.8 & -5.3 & -5.6 & -4.0 \\
\hline \multirow[t]{2}{*}{$25-50 \%$} & 13.2 & 12.0 & 12.4 & 11.2 & 13.3 & 12.4 \\
\hline & -2.7 & -3.1 & -3.7 & -4.4 & -10.4 & -3.6 \\
\hline \multirow[t]{2}{*}{$50-55 \%$} & 14.6 & 18.2 & 14.8 & 12.2 & 16.5 & 15.7 \\
\hline & -2.8 & -3.1 & -3.7 & -4.8 & -8.7 & -4.3 \\
\hline \multirow[t]{2}{*}{$55-60 \%$} & 16.0 & 14.3 & 12.0 & 17.9 & 15.3 & 14.9 \\
\hline & -2.6 & -3.2 & -3.7 & -5.2 & -9.6 & -3.8 \\
\hline \multirow[t]{2}{*}{$60-65 \%$} & 16.2 & 15.7 & 13.4 & 15.2 & 16.8 & 15.4 \\
\hline & -2.8 & -3.0 & -3.7 & -4.6 & -4.7 & -4.4 \\
\hline \multirow[t]{2}{*}{$65-70 \%$} & 15.1 & 14.8 & 14.3 & 14.2 & 21.9 & 15.2 \\
\hline & -2.6 & -3.2 & -3.8 & -4.9 & -10.7 & -4.1 \\
\hline \multirow[t]{2}{*}{$70-75 \%$} & 17.1 & 16.1 & 15.1 & 16.5 & 15.3 & 16.0 \\
\hline & -2.7 & -3.1 & -3.7 & -4.6 & -9.5 & -4.2 \\
\hline \multirow[t]{2}{*}{$75-80 \%$} & 13.8 & 17.4 & 15.0 & 18.0 & 15.3 & 16.0 \\
\hline & -2.7 & -3.1 & -3.8 & -5.0 & -7.9 & -4.3 \\
\hline \multirow[t]{2}{*}{$80-85 \%$} & 17.5 & 16.2 & 16.3 & 15.9 & 15.8 & 16.5 \\
\hline & -2.7 & -3.2 & -3.8 & -5.1 & -7.9 & -4.2 \\
\hline \multirow[t]{2}{*}{$85-90 \%$} & 16.0 & 17.0 & 17.2 & 16.4 & 16.5 & 16.7 \\
\hline & -2.6 & -3.1 & -3.8 & -5.0 & -8.5 & -4.6 \\
\hline \multirow[t]{2}{*}{$90-95 \%$} & 19.6 & 19.0 & 17.7 & 17.0 & 15.8 & 17.5 \\
\hline & -2.7 & -3.2 & -3.8 & -4.9 & -9.9 & -5.4 \\
\hline \multirow[t]{2}{*}{$95-100 \%$} & 15.7 & 17.8 & 19.3 & 17.4 & 16.4 & 17.0 \\
\hline & -2.7 & -3.1 & -3.6 & -4.9 & -8.6 & -6.4 \\
\hline Column & 15.3 & 15.8 & 15.1 & 15.6 & 15.9 & 15.5 \\
\hline Average & -2.7 & -3.1 & -3.7 & -4.9 & -8.8 & -4.7 \\
\hline
\end{tabular}

Average annual Social Security income (top number in each cell) and reduction in benefits from wealth test (bottom number) are reported in $\$(000)$ dollars. Respondents with the top and bottom one percent of total wealth, out of range age respondents and respondents without Social Security income are excluded. Total benefits are not allowed to fall below zero after the means test. 
Turn now to Table 4, which reports results only for the top five ventiles of the wealth distribution. The wealth test is analogously designed, with the benefit reduction aimed at reducing the benefit of those who fall in the top quarter of wealth holders. Here the proportionate reduction in Social Security benefits would be applied to the wealth of the individual. Once again the proportionate wealth test is designed to generate the same total benefit reduction as would a $\$ 5,000$ benefit reduction applied to all individuals who fall in the top quarter of the wealth distribution.

From the bottom row of Table 4, right hand column, for the top quarter of wealth holders, average benefits for affected individuals are reduced by 30.3 percent (4.7/15.5). The cell in column 5, next to last row, pertains to the top ventile of wealth holders who also fall in the top ventile of income recipients. Their average benefits are $\$ 16,400$, while the reduction in their benefits from the means test is $\$ 8,600$, or 52.4 percent. Those falling in the top row, left hand column, are from the bottom quarter of income recipients and fall within the $75^{\text {th }}$ to $80^{\text {th }}$ percentiles of wealth holders. Their average benefits of \$8,200 are reduced by $\$ 2,600$, or by 31.7 percent.

Now consider the effects of a means test based on wealth when evaluated from the perspective of a person who considers income as the proper way to judge an individual's means. Look down the last column of Table 4. From row 1, a person falling in the bottom quarter of income recipients will have their Social Security benefit of $\$ 7,900$ reduced by $\$ 4,000$, or 50.6 percent. From the next to bottom row of Table 4, last column, a person falling in the top ventile of the income distribution will have their $\$ 17,000$ benefit reduced by $\$ 6,400$, or by 37.6 percent. That is, for those falling in the top quarter of the wealth distribution, the means test based on wealth reduces the benefit of the individuals with the lowest incomes by a rate that is thirteen 
Table 5: Social Security Reduction in Benefits from Income and Wealth Tests, Original HRS Cohort in 2010, Ages 69 to 79, weighted

\begin{tabular}{|c|c|c|c|c|c|c|c|c|c|c|c|c|c|}
\hline $\begin{array}{l}\text { Wealth/ } \\
\text { Income }\end{array}$ & $\begin{array}{l}\text { Wealth } \\
0-25 \%\end{array}$ & $25-50 \%$ & $50-55 \%$ & $55-60 \%$ & $60-65 \%$ & $65-70 \%$ & $70-75 \%$ & $75-80 \%$ & $80-85 \%$ & $85-90 \%$ & $90-95 \%$ & $95-100 \%$ & $\begin{array}{c}\text { Row } \\
\text { Average }\end{array}$ \\
\hline Income & 0 & 0 & 0 & 0 & 0 & 0 & 0 & 0 & 0 & 0 & 0 & 0 & 0 \\
\hline $0-25 \%$ & 0 & 0 & 0 & 0 & 0 & 0 & 0 & -2.6 & -3.1 & -3.8 & -5.3 & -5.6 & -4.0 \\
\hline \multirow[t]{2}{*}{$25-50 \%$} & 0 & 0 & 0 & 0 & 0 & 0 & 0 & 0 & 0 & 0 & 0 & 0 & 0 \\
\hline & 0 & 0 & 0 & 0 & 0 & 0 & 0 & -2.7 & -3.1 & -3.7 & -4.4 & -10.4 & -3.6 \\
\hline \multirow[t]{2}{*}{$50-55 \%$} & 0 & 0 & 0 & 0 & 0 & 0 & 0 & 0 & 0 & 0 & 0 & 0 & 0 \\
\hline & 0 & 0 & 0 & 0 & 0 & 0 & 0 & -2.8 & -3.1 & -3.7 & -4.8 & -8.7 & -4.3 \\
\hline \multirow[t]{2}{*}{$55-60 \%$} & 0 & 0 & 0 & 0 & 0 & 0 & 0 & 0 & 0 & 0 & 0 & 0 & 0 \\
\hline & 0 & 0 & 0 & 0 & 0 & 0 & 0 & -2.6 & -3.2 & -3.7 & -5.2 & -9.6 & -3.8 \\
\hline \multirow[t]{2}{*}{$60-65 \%$} & 0 & 0 & 0 & 0 & 0 & 0 & 0 & 0 & 0 & 0 & 0 & 0 & 0 \\
\hline & 0 & 0 & 0 & 0 & 0 & 0 & 0 & -2.8 & -3.0 & -3.7 & -4.6 & -4.7 & -4.4 \\
\hline \multirow[t]{2}{*}{$65-70 \%$} & 0 & 0 & 0 & 0 & 0 & 0 & 0 & 0 & 0 & 0 & 0 & 0 & 0 \\
\hline & 0 & 0 & 0 & 0 & 0 & 0 & 0 & -2.6 & -3.2 & -3.8 & -4.9 & -10.7 & -4.1 \\
\hline \multirow[t]{2}{*}{$70-75 \%$} & 0 & 0 & 0 & 0 & 0 & 0 & 0 & 0 & 0 & 0 & 0 & 0 & 0 \\
\hline & 0 & 0 & 0 & 0 & 0 & 0 & 0 & -2.7 & -3.1 & -3.7 & -4.6 & -9.5 & -4.2 \\
\hline \multirow[t]{2}{*}{$75-80 \%$} & -2.9 & -2.8 & -2.9 & -2.8 & -2.8 & -2.7 & -2.8 & -2.9 & -2.9 & -2.9 & -2.9 & -2.9 & -2.8 \\
\hline & 0 & 0 & 0 & 0 & 0 & 0 & 0 & -2.7 & -3.1 & -3.8 & -5.0 & -7.9 & -4.3 \\
\hline \multirow[t]{2}{*}{$80-85 \%$} & -3.4 & -3.3 & -3.2 & -3.4 & -3.3 & -3.4 & -3.4 & -3.3 & -3.4 & -3.4 & -3.4 & -3.3 & -3.3 \\
\hline & 0 & 0 & 0 & 0 & 0 & 0 & 0 & -2.7 & -3.2 & -3.8 & -5.1 & -7.9 & -4.3 \\
\hline \multirow[t]{2}{*}{$85-90 \%$} & -4.0 & -4.1 & -4.2 & -4.0 & -4.1 & -4.1 & -4.1 & -3.9 & -3.9 & -4.1 & -4.0 & -4.1 & -4.0 \\
\hline & 0 & 0 & 0 & 0 & 0 & 0 & 0 & -2.6 & -3.1 & -3.8 & -5.0 & -8.5 & -4.6 \\
\hline \multirow[t]{2}{*}{$90-95 \%$} & -5.1 & -5.3 & -5.1 & -5.0 & -5.3 & -5.3 & -5.2 & -5.1 & -5.2 & -5.0 & -5.2 & -5.4 & -5.2 \\
\hline & 0 & 0 & 0 & 0 & 0 & 0 & 0 & -2.7 & -3.2 & -3.8 & -4.9 & -8.6 & -6.4 \\
\hline \multirow[t]{2}{*}{$95-100 \%$} & -9.3 & -8.5 & -7.7 & -10.6 & -8.3 & -8.9 & -7.1 & -8.3 & -8.4 & -8.7 & -8.9 & -9.1 & -8.9 \\
\hline & 0 & 0 & 0 & 0 & 0 & 0 & 0 & -2.7 & -3.1 & -3.6 & -4.9 & -8.6 & -6.4 \\
\hline Column & -4.9 & -4.2 & -4.1 & -4.8 & -4.4 & -4.1 & -4.1 & -4.3 & -4.8 & -4.6 & -5.2 & -6.6 & -4.9 \\
\hline Average & 0 & 0 & 0 & 0 & 0 & 0 & 0 & -2.7 & -3.1 & -3.7 & -4.9 & -8.8 & -4.7 \\
\hline
\end{tabular}

Average annual Social Security reductions in benefits from the income and wealth tests are reported in $\$(000)$ dollars. Respondents with the top and bottom one percent of total income and wealth, out of range age respondents and respondents without Social Security income are excluded. Total benefits are not allowed to fall below zero after the means test. 
percentage points higher than the benefit reduction that will be experienced by individuals falling in the top of the income distribution.

Table 5 provides a ready comparison of the benefit reductions due to means tests based on income and wealth. In each cell, the top figure indicates the benefit reduction due to a means test based on income, while the bottom figure reports the benefit reduction due to a means test based on wealth. The upper left hand quadrant is all zeros. The individuals there do not have high enough incomes or wealth to fall in the top quarter of individuals ranked by either criterion. Those in the bottom right hand quadrant have both income and wealth high enough to be subject to a means test, whether it is based on income or wealth.

By construction of a means test that is a fixed proportion of income, the dollar value of the benefit reduction from the means test is the same whether the individual has the highest or lowest wealth. Similarly, the dollar value of the benefit reduction due to a means test that is a fixed proportion of wealth is the same no matter where the individual falls in the income distribution. In terms of target efficiency, and the policy maker's view of equity, it clearly matters whether the means test is based on income or wealth. Moreover, it also matters a great deal whether the effectiveness of the means test is judged by its impact on those in different parts of the income distribution, or whether its effect is judged by the impact of the means test on those falling in different parts of the wealth distribution. In designing a means test for Social Security, it is important to define what the policy maker means by "high means". Moreover, granting that a means test based on wealth is more difficult to administer than a means test based on income, if one feels that wealth is the appropriate criterion for evaluating means, then means testing based on income will be far from a perfect substitute for a means test based on wealth. 


\section{Related Findings and Additional Issues}

It is useful to note that these basic findings are preserved when the means test is applied at the level of the household rather than the individual; and similarly when households are separated into married couples and singles. Of course the levels of benefit reductions are different when the means test is based on the household rather than the individual. But the bottom line with regard to whether the means test is based on income or wealth, and the policy maker's preference as to whether the means test should be based on income or wealth, is the same. $^{12}$

To be sure, the change in the benefit from a particular means test experienced by a given individual will depend on how the unit subject to the means test is defined. For example, a single person household falling in the top quarter of all single person households when ranked by income, will not fall in the top quarter of households when single person and married couple households are pooled into one group. Thus a given individual will experience a different change in benefits from a means test depending on whether the appropriate unit for evaluating means is taken to be the individual, the household, or whether married households and single households are considered separately. Moreover, there are different approaches to determining the relevant rates to apply to single person or couple households. But the major message remains. Means tests based on income or wealth have different distributional consequences, and the view of the appropriateness of a means test depends on the extent to which the policy maker values redistribution based on income relative to redistribution based on wealth.

It can also be shown that major differences may arise when other definitions of means are used. In Gustman, Steinmeier and Tabatabai (2014c) we explore the distributional differences

\footnotetext{
${ }^{12}$ Not all of the data required for means testing at the household level are readily available to the Social Security Administration. Social Security does not aggregate individuals into households until after retirement, and even then does not do so for all households. For further discussion, see (Compson, 2011, fn. 5).
} 
when means tests are based on total wealth, lifetime covered earnings, the wealth value of pensions, and a measure of lifetime W2 earnings. The bottom line, once again, is that policy makers who advocate means tests need to be quite clear about how they want to define means, and in how they view means tests when alternative measures of means are considered.

While the focus in the present paper is naturally on the divergence between the income and wealth distributions within a cohort of older households, one might ask about the divergence between the income and wealth distributions for younger cohorts (e.g., people in their forties). Here one would expect to see some differences in these relations. Earnings at younger ages account for the bulk of income. Income shocks at younger ages are driven by job changes, including involuntary separations, early health problems and household labor supply decisions. For the older cohorts we consider, the importance of earnings has been minimized. Similarly the determinants of wealth are different between members of younger and older cohorts. The major motivations for saving by those in their forties are just changing from a precautionary demand, saving for a home, and saving for children's educational expenditures, to a life cycle motivation. Accruals in pension accounts are low at younger ages. Moreover, there are cohort differences in types and accrual rates of pensions. For further discussion of saving motivations, see the survey in Gustman and Juster (1996).

While our measure of income has the feel of adjusted gross income for a tax return, it is pretty far from a comprehensive measure of income. For example, owner-occupied housing is a very important concern for retirees -- retiring with a fully paid off mortgage implies a substantial stream of consumption in retirement compared to someone who plans on renting a place to live during retirement. It is possible to deal with imputed rental income. But there are practical difficulties. Some houses have not been brought to market in many years. Their self-reported 
values may be quite far from true market values, so that imputed rental income from housing may be subject to considerable error. For these same reasons, one may question whether housing should be included in wealth. Moreover, housing is often used by older households as a source of insurance, with the house not sold until one or another spouse falls ill or dies. Yet as seen in Appendix Table 2A, housing is a major source of wealth for older households, accounting for over one fifth of total wealth. This makes housing wealth hard to ignore when framing a means test for Social Security based on wealth, and also argues for including imputed rent when evaluating income for a means test. These and related questions of which sources of income or wealth to include in a means test, and how to include considerations based on practicality, should certainly be subject to further discussion among policy makers before any means tests are implemented.

Another question that should be addressed before any means tests are implemented is how to treat wealth in qualified accounts vs. wealth on which taxes have already been paid. Analogously, what is the appropriate way to treat income from these accounts? Should income be measured before or after taxes? More importantly, if the after tax value of withdrawals from pension accounts is treated as income, how should one treat withdrawals from accounts on which taxes have already been paid? Is it the tax status of an account that should determine whether it is relevant when means testing, or is it the ability to support a consumption standard outside of Social Security income that is relevant? What are the implications for saving and withdrawal of wealth of the different bases for means testing based on income and wealth?

Means tests do not standardize for age or cohort. Yet wealth declines with age as annuity values fall and as balances are withdrawn to support consumption. Thus the same individual that was considered to be high wealth at age 62 will fall much further down the wealth distribution at 
age 80. This will be so even if the individual remains at the top of income recipients from their cohort throughout the period from retirement through death. Yet if means tests based on wealth do not standardize for age, means testing will reduce benefits more at younger than at older ages simply because younger retirees have more years to go in retirement. Analogously on the income side, interest, dividends and capital gains -- not the withdrawal of funds from the account, will be high right after retirement, but will fall as the nest egg gets depleted.

\section{Conclusions}

To put the benefit reductions considered here into perspective, consider the following two numbers. Citing the Social Security Board of Trustees, Steven Goss (2010) indicates that a 13 percent benefit cut would be sufficient to allow full payment of Social Security benefits for 75 years. The means tests examined here would reduce the benefits of our full sample of 69 to 79 year olds by about 9 percent of the average benefit before the means test. Thus the means tests considered here might be capable of closing somewhat less than three fourths of the Social Security funding gap, at least for members of this cohort over the age span considered here.

We have shown that a means test of this size may have very different distributive implications, depending on the basis for the means test. Deciding on a basis for means testing would be easy if those with high Social Security benefits also had high current income and high wealth. But as we have seen, that is not the case for many. As a result, different individuals will be affected as the basis for the means test is changed. Which definition of means is chosen will make a great deal of difference, at least to some individuals, and to policy makers with different views as to what we mean by high means. ${ }^{13}$

\footnotetext{
${ }^{13}$ See Samwick (2012) and Samwick and Zhou (2014) for related discussions in the context of means testing health benefits and financial aid for college education.
} 
Our hope is that policy makers will be aware of the differences that alternative approaches to means testing may make, giving them a better understanding of the strengths and weaknesses of alternative definitions of means. The ultimate choice of policy, as always, depends on the preferences of the policy maker. But it is important that the complexities associated with the different choices are fully understood.

There are other important issues. Implementing a means test based on wealth would require the Social Security Administration to collect more data than is currently available. For one thing, it would be necessary to link all husbands and wives so that their wealth could be allocated between them. Yet husbands and wives are linked in Social Security data only when they reach retirement age, and those linkages are made only when spouse or survivor benefits are paid. In addition, there are the costs of collecting measures of wealth. Trying to determine pension wealth, for example, would be administratively costly and require extensive new data collection. To be sure, data on the amounts in defined contribution plans and expected benefits from defined benefit pensions are collected for administering other programs. For example, the SSI program requires this type of information. ${ }^{14}$ Similarly, when calculating offsets for work in uncovered employment, the Social Security Administration prorates the value of lump sum funds taken from a defined contribution pension to determine the equivalent annual pension. The important point is that there are methods for converting stocks into flows and vice versa. Actuaries move between stocks and flows when calculating pension liabilities, and so does the Social Security Administration. If it was decided to include pension wealth in total wealth, this

\footnotetext{
14 "SSI does not treat assets in defined benefit and defined contribution retirement plans in the same manner. Beneficiaries of a defined benefit plan must apply for pension benefits when qualifications are met, and those benefits offset the SSI payment, but SSI applicants and recipients are allowed to retain the asset until it can be annuitized. By contrast, holdings in a defined contribution plan must be reduced or eliminated, depending on the amount of the holdings, for the SSI applicant or recipient to be eligible for SSI.” See Parent (2006) for further discussion.
} 
could be done using a standard approach with appropriate interest rates (e.g., from the Trustees Report) and SSA life tables. A third issue is that applying a means test to those in their early or mid-sixties will raise the tax on earnings, discouraging labor market participation by these older individuals. That policy would fly in the face of many types of government initiatives designed to encourage delayed retirement in line with growing life expectancies.

In concluding, it is worth elaborating on a caveat with regard to disincentives created by each approach. Using current income as a basis for a means test would discourage the population from delaying retirement. Moreover, a means test based on income would affect the course of realization of wealth. The implied marginal tax rate on current income is substantial at 7.5 percent (a \$5,000 reduction on an average income of the top 25 percent of around \$66,000). This figure is high enough that it may have nontrivial negative implications for the decision as to whether to defer income to retirement via an IRA or 401(k). If wealth is used as the basis for the means test, the means test is equivalent to a wealth tax of about 0.5 percent per year $(\mathrm{a} \$ 5,000$ reduction on an average wealth of the top 25 percent of around \$926,000). Another number of interest is how many individuals have their benefits zeroed out with either an income or wealth based means test. From the numbers in Tables 2-4, relatively few have their benefits zeroed out, meaning that most affected individuals will be subject to these higher marginal tax rates. This is on top of a Medicare income related adjustment that works out to around 3 percent for individuals with incomes between $\$ 85,000$ and $\$ 214,000$.

Taxing wealth of different kinds would also create other disincentives, for example, reducing incentives to save, or to participate in a pension. These disincentives will play a major role in shaping the benefits and costs of any proposal to means test Social Security. 


\section{REFERENCES}

American Academy of Actuaries. 2012. “Means Testing for Social Security: Issue Brief”. December.

Compson, Michael C. 2011. “The 2006 Earnings Public Use Micro Data File”. Social Security Bulletin 71(4): 33-60.

Goss, Steven C. 2010. “The Future Financial Status of the Social Security Program”. Social Security Bulletin 70(3): 111-125.

Gustman, Alan L. and F. Thomas Juster. 1996. "Income and Wealth of Older American Households: Modeling Issues for Public Policy Analysis". In Hanushek, Eric A. and Nancy L. Maritato (eds.), Assessing Knowledge of Retirement Behavior, 11-60. National Academy Press, Washington, D.C.

Gustman, Alan L., Thomas L. Steinmeier, and Nahid Tabatabai. 2014a. “The Social Security Windfall Elimination and Government Pension Offset Provisions for Public Employees in the Health and Retirement Study”. Social Security Bulletin 74(3): 55-69.

Gustman, Alan L., Thomas L. Steinmeier, and Nahid Tabatabai. 2014b. "Mismeasurement of Pensions Before and After Retirement: The Mystery of the Disappearing Pensions with Implications for the Importance of Social Security as a Source of Retirement Support". Journal of Pension Economics and Finance 13(1): 1-26.

Gustman, Alan L., Thomas L. Steinmeier, and Nahid Tabatabai. 2014c. "Distributional Effects of Means Testing Social Security: An Exploratory Analysis”. NBER Working Paper 20546. October.

Moffitt, Robert A. 2016. Means-Tested Transfer Programs in the United States. Chicago: University of Chicago Press. Robert A. Moffitt, editor.

Parent, Rene. 2006. "Defined Contribution Pension Plans and the Supplemental Social Security Program”. Policy Brief 2006-01. Social Security Administration, Washington, D.C.

Purcell, Patrick. 2015. “Income Taxes on Social Security Benefits”. Issue Paper No. 2015-02. December. Social Security Administration, Washington, D.C.

Samwick, Andrew A. 2012. “Means Testing Federal Health Entitlement Benefits”. Manuscript. Hanover, N.H.

Samwick, Andrew A. and William L. Zhou. 2014. “The Insurance Value of Financial Aid”. Manuscript. Hanover, N.H. 
Social Security Administration. 2012. Annual Statistical Supplement to the Social Security Bulletin. Social Security Administration, Washington, D.C.

Social Security Administration. 2014. Income of the Population 55 and Older, 2012. Social Security Administration, Washington, D.C.

The Board of Trustees, Federal Old-Age and Survivors Insurance and Federal Disability Insurance Trust Funds. 2015. "The 2015 Annual Report of the Board of Trustees of the Federal Old-Age and Survivors Insurance and Federal Disability Insurance Trust Funds”. Washington, D.C.

Wimer, Christopher and Lucas Manfield. 2015. "Elderly Poverty in the United States in the $21^{\text {st }}$ Century: Exploring the Role of Assets in the Supplemental Poverty Measure. CRR Working Paper 2015-29. November. Center for Retirement Research, Boston College. Boston, MA. 
Appendix Table 1A: Components of Income for Original HRS cohort in 2010, weighted

\begin{tabular}{|l|c|}
\hline Components of Income & Average \\
\hline Earnings & $\$ 3,433$ \\
\hline Social Security retirement income & 13,088 \\
\hline Pension and Annuity & 5,427 \\
\hline $\begin{array}{l}\text { Supplemental Security income \& } \\
\text { social security disability income }\end{array}$ & 89 \\
\hline Unemployment and workers comp & 78 \\
\hline Other government transfer & 925 \\
\hline Capital income & 5,949 \\
\hline Other income & 1,027 \\
\hline Total & 30,015 \\
& $(4740)^{*}$ \\
\hline
\end{tabular}

*Number of observations in the age group. 
Appendix Table 2A: Components of Wealth for Original HRS cohort in 2010, weighted

\begin{tabular}{|l|c|}
\hline Components of Wealth & Average \\
\hline Present value of social security & $\$ 143,323$ \\
\hline Present value of pension and annuity & 47,769 \\
\hline House & 111,653 \\
\hline Real estate & 26,747 \\
\hline Business & 23,871 \\
\hline Finances & 99,026 \\
\hline IRAs & 45,886 \\
\hline Vehicle & 9,298 \\
\hline Total & 507,573 \\
& $(4740)^{*}$ \\
\hline
\end{tabular}

*Number of observations in the age group. 